\title{
Translations of William Shakespheare's Tragedy "Hamlet" In Uzbek Literature Studies
}

\author{
Jeyren Mizrabova
}

\begin{abstract}
Shakespeare's works are classics in literature and have many translations. The aim of the work is to study the peculiarities of the translations of William Shakespeare's tragedy "Hamlet" in Uzbek literary criticism. In particular, the history of the creation of translations of this work into the Uzbek language, their quality and personality of the authors, the distinctive features of each of them and the circumstances of their origin have been studied. Particular attention is paid to the personality of Jamal Kamal, the author of the first translation of William Shakespeare directly from the original language. Also, the history of Uzbek indirect and direct transfers is briefly outlined, and a study is made about their extremely important influence in the development of culture. An important source of information here are various scientific works that cover and analyze the works of Uzbek translators with the works of William Shakespeare. A comparative-analysis of the peculiarities of translation of verbal images in the speech of the main characters into Russian and Uzbek languages is carried out, their correspondence to the original and the used interpreting techniques are analyzed. The conclusion about quality and prospects of development of the Uzbek direct translation are outlined.
\end{abstract}

Keywords : tragedy, Hamlet, translation, character, direct translation, literary movement, stage, Shakespeare, features of translation, independence.

\section{INTRODUCTION}

If the XX century was called as the translation century in the history of the world civilization but the XXI century is called as a period of literary translation. Uzbek translation also had great achievements in the last century and Uzbek readers were acquainted with masterpieces of the world literature. Independence has opened broad ways as to literary movement so to the direct translation also. Shakespeare's works are not limited to a particular period or the literary environment of a particular people. Shakespeare visited different nations not at the same time, but at different times. For example, Russians, Ukrainians, Armenians started to translate great dramatist's works in the early XXth. Central Asian nations, including Uzbeks, enjoyed the samples of Shakespeare's works only after October Revolution. It is well known that firstly the dramatic heritage of Shakespeare was not translated from original language and into Uzbek they were translated from Russian. Direct translation is not an easy matter by itself. In Uzbekistan direct translations of

Revised Manuscript Received on July 22, 2019.

Jeyren Mizrabova , Doctoral Candidate, Bukhara State University, Bukhara,Uzbekistan, 98765432.mamedov@mail.ru
Shakespeare's works have been achieved during the years of independence. For the first time Shakespeare's Hamlet tragedy was translated into Uzbek in 1934. It was in the 30s, and the Uzbek nation of that time was surprised and glad to watch the tragedy, and it was some kind of auspicious event in their cultural life. Firstly, Shakespeare's verse was translated into Uzbek in prose and there were many linguistic defects, misinterpreted events, but this translation has its own value. Obviously, this old translation cannot be compared to the current version of Jamol Kamal's. But Chulpan's translation was the first translation that came to us for the first time which delivered the magic of the great English writer. Really, that was a brave step.

\section{MATERIALS AND METHODS}

An important source of information here are various scientific works that cover and analyze the works of Uzbek translators with the works of William Shakespeare. A comparative-analysis of the peculiarities of translation of verbal images in the speech of the main characters into Russian and Uzbek languages is carried out, their correspondence to the original and the used interpreting techniques are analyzed. Translations which were done by great Uzbek poets and writers as Abdulla Qodiriy, Chulpon, Usmon Nosir, A'zam Ayub, Otajon Khoshim, Sanjar Siddiq, Mannon Royiq were a milestone in the development of uzbek translation practice and it's theory. Their traditions were continued by Oybek, G'afur G'ulom, Abdulla Qakhhor, Maqsud Sheikhzoda, Zulfiya, Mirtemir, Mirzakalon Ismoiliy and others. Shakespeare was the first mentioned in Uzbek in Chulpon's translation of the recognizable tragedy "Hamlet". Familiarization of the mentioned tragedy in Uzbek literary movement came in three stages:

1) indirect translation in prose ( by Chulpan in 1934 y.), [1]

2) indirect translation in verse ( by Maqsud Shaykhzoda twice (in 1940), (in 1948)) [2] 3 ) direct translation (by Jamol Kamol in 1991). [3]

The earliest mention of Shakespeare penetrated Uzbekistan via Russian publications. In XX century his works would frequently be transported to Uzbek from Russian adaptations by B. Pasternak, M. Lozinskiy, P. A. Kanshin, G. L. Shchepkina-Kupernik, B. D. Levin. We cannot overlook Jamol Kamol's translations from the original of several works by Shakespeare, this was indeed novelty and the translation itself won a large audience.

The cult of Shakespeare in XX century had been prepared by Uzbek authors and poets and they followed Shakespeare's sample in creating a specific national literature, 
founded on the comprehension of the national spirits. Maqsud Sheikhzoda remains the most outstanding representative of Uzbek Shakespearializm. Maqsud Sheikhzoda set himself a goal, to create tragedies in Uzbek literature, and in this he had better success than anyone else. In the manner of our Father Shakespeare Uzbek poets and authors created their tragedies as "Mirzo Ulug'bek" , “ Ulug'bek's star " by Maqsud Shaykhzoda, "Jaloliddin”, “ Muqanna” by Khamid Olimjon, " Navoiy " by Oybek and so on.

G'aybullo Salomov, Fozila Sulaymonova were among the first critics to embrace the realistic method of Shakespeare proving him to be a true humanist and democrat: in Gaybullo Salomov's opinion “Shakespeare's creative works are the Great University of the mankind" [4, 6-9.]. Ibrokhim Khaqqul regarded him as " genius who achieved to put together the world art, culture and morality" $[5,71$.

The XX century Uzbek literature saw many translations of Shakespeare done by Chulpon, G'afur G'ulom, Maksud Sheikhzoda, Asqad Mukhtor, Turob To'la, Uyg'un, Yusuf Shomansur, Jamol Kamol and others. In the last third of the XX century, there began academic scholarship of Shakespeare, its founder being Gaybullo Salomov, whose first works on Shakespeare appeared still in the (1979), Fozila Sulaymonova in (1978), Elvira Aznaurova in (1973), Dildor G'ulomova in (1975). In 1982 Gaybullo Salomov published valuable research work on the language and style of Shakespeare, his work embraced a whole range of issues (creative work, theater, translation problems, artistic method). Fozila Sulaymonova's book contained a lot of literary aspects (literary environment, biography, creative work, theater). Various aspects were dicussed in works by Ibrokhim Khaqqul, Ninel Vladimirova, Jumaniyoz Sharipov, Bakhtiyor Nazarov, Mukhammadjon Kholbekov and others. The Uzbek theater contributed high-quality versions of Shakespearean tragedies as "Hamlet" ( directed by Mannon Uyg'ur (1935), starring Abror Khidoyatov, Sora Eshonto'rayeva, Olim Kho'jayev), and Othello ( dir. N. V.Lodigin and Mannon Uyg'ur 1941, starring Nabi Rakhimov, Sora Eshonto'rayeva, Shukur Burkhonov).

More than four centuries after the birth of the great and highly esteemed playwright William Shakespeare, scientists, art professionals and book lovers in Uzbekistan and elsewhere continue to admire his poetic legacy. After all, as long as the name of Shakespeare is passed down from one generation to another and his creations are loved and recognized he will live forever in the hearts of people. $\mathrm{He}$ made a massive contribution to the world literature and it is gratifying to see that his works are being piqued the interest of reader all over the world.

\section{DISUSSION}

One of the foremost Elizabethan tragedies in the canon of English literature is "Hamlet" by William Shakespeare. "Hamlet" is one of the most recognizable and most often quoted tragedies in all of English literature. The tragedy of "Hamlet" is generally considered as enigma. It differs from Shakespeare's other tragedies as well as from the works in that it's course of action never fails to surprise and bewilder the spectator. Hamlet expresses with extraordinary power, two completely new and profound character, whose distinguishing feature is the absence of character and that only the genius of a Shakespeare could create such a profound character.

Hamlet is unsolvable riddle, but no one finds the courage to say that the emperor is naked, that it is perfectly plain that Shakespeare was either unable or unwilling to give Hamlet a specific character. And so the scholarly critics continue to study, investigate and extol this mysterious literary production.

Aristotle who is concerned with the proper presentation of tragic plays and poetry defines tragedy as : “ representation of an action that is worth serious attention complete in itself and of some amplitude ; in language enriched by variety of artistic devices appropriate to the several parts of the play: presented in the form of action, not narration of such emotion."

In each Shakespeare's works you may see various aspects of tragedy which we come across in our lives. In this regard, tragedy takes beginning out of relations around the family in the terms of relations between husband and wife, among mother and children or relatives. As a result these relationships unify into a social issues.

Shakespeare's works were translated and currently are being translated into many languages. For example, during XVIII - XX centuries the tragedy "Hamlet" was translated into Russian 23 times ( monologue by Hamlet 34 times ). Similarly, it was translated into Uzbek 3 times. As we said before, the first Uzbek translation was done by Chulpon in 1934, the second by Maksud Sheikhzoda in 1948 and the third was done by Jamol Kamol. Uzbek poet and translator Jamol Kamol's attitude towards genius of Shakespeare was not ordinary, he could enter into playwright's spiritual world. A pity song which was sang by Shakespeare made translator's heart to sing the same song. Shakspeare's poetry flows in tunes. His comedies are flow of spirits and his tragedies are flow of soul. Despite the fact that some Russian translators translated his works rhythmless or in prose. Uzbek poet Jamol Kamol read genius's works in original and discovered that his poetry didn't just contain but had tremendous amount of rhymes. All in all, we are proud and can say that in our literature are made the first steps in the sphere of translation of Shakespeare's works from original into our native language. So genius's masterpieces are shining in a new beauty and splendor.

The most impressive part of tragedy is Hamlet's monologue ." To be or not to be " is the most famous soliloquy among the works of Shakespeare - probably even, the most famous soliloquy anywhere. The question for Hamlet was whether to continue to exist or not- whether it was more noble to suffer the slings and arrows of an unbearable situation, or to declare war on the sea by opposing them and end them. Hamlet is thinking about life and death and pondering a state of being versus a state of not being being alive and being dead. The translations of this monologue into Russian ( To be, or not to be ) are as follows;

“ Быть или не быть- таков вопрос " by M. Vorochenko, ( 1829 ); “ Быть или не быть? 
Вот в чём вопрос !” by ( A. Rozenberg, 1844 ) ; “ Быть или не быть: вот в чём вопрос “ by ( B. Pasternak, 1940 ) etc. As we can see all of these versions are almost all alike. This part of soliloquy was translated into Uzbek as follows: by Chulpon “Ё хаёт, ё ўлим, масала шунда" ; by Maksud Sheikhzoda “ Тирик қолмоқ ё ўлмоқ ? Шудир масала! , and by Jamol Kamol “Ё хаёт, ё мамот: масала шундоқ “. If we analyze all of them we can see that two of Uzbek translations are made in accordance with Russian versions. For example, if we compare these translations with original text we can see that Chulpon's translation similarly to M. Lozinsskiy's version and M. Sheikhzoda's translation to B. Pasternak's but Jamol Kamol translated from original and differs from before made translation texts, because he knew English.

Talented Uzbek poet and translator Jamol Kamol's attitude towards genius of Shakespeare was not ordinary, he could enter into playwright's spiritual world. A pity song which was sang by Shakespeare made translator's heart to sing the same song. Shakespeare's poetry flows in tunes. His comedies are flow of spirits and his tragedies are flow of soul. Jamol Kamol learned English to translate the great Bard's masterpieces independently. In "Hamlet" - like in most Shakespeare's plays - the nobles typically speak in unrhymed "iambic pentameter" ( also called blank verse). An "iamb" is unaccented syllable followed by an accented one. "Penta" means "five", and "meter" refers to a regular rhythmic pattern. The stanza which contains " To be, or not to be " condensed a life scene which is described in tragedy.

As Uzbek translator knew English language so, Jamol Kamol could create a fresh and vivid characters from Shakespeare's plays and translated the beginning of Hamlet's soliloquy as follows:

Ё хаёт, ё мамот: масала шундоқ.

Жоизмикин ул жобиру жаббор фалакнинг

Жафосига хар дақиқа чидаса юрак?

Ё балолар денгизига кўндаланг бўлиб 87 ]

Койишлару ташвишларга чек кўймоқ керак ?

Jamol Kamol talks about Shakespeare in a language that is understandable and familiar to us, recreating the ease and coziness of our native place. This makes it the more obvious that the translation from English performed by the Uzbek poet was not a means of subordinating. Even the first translation of the tragedy "Hamlet" made by famous Uzbek writer and poet was in prose yet, it is the first one. A fore cited translation by Chulpan was run the gauntlet. The cause for such roast criticism was vulgar socialism of the 20-30s. The author was unjustly impeached as nationalist. The primary translation became a reason for impetuous polemics in literary movement and in social and political journalism of that period. Chulpon was a brave fighter for freedom and justice. In his renewed words are perceptible Hamlet's spirit: “Улуғ, қаттиқ ағдарувчи бир кўраш. Ё бор бўлиш, ё йўқ бўлиш: йўқ яраш” (literal translation is the following; “ "The great powerful revolt. To be, or not to be: no truce.") and here is obviously Shakespeare's passion is noticeable. Many literary and scientific works are being devoted to Chulpon's oeuvre and life. For instance, in the staged play “Занжирбанд шер” (“The chained lion”) by Ziyo Najmiy hero Chulpon not only mentally reproduces all the events but expresses his own attitude due the developments. And here Hamlet's image succors an Uzbek poet fighter. Uzbek ponders about all rottenness and ignobility around him, about hypocrisy of his "friends", about his enemies. About how betrayal and dishonor become a common and normal condition in the course of life. But honor and justice embarrassed and oppressed. Inspired by Shakespearean hero in order not to feel his own weakness he realizes that life is a struggle. Although, hero Chulpon was dethroned physically but morally he won a victory. Before spectators eyes on the stage there was an image of proud and noble man who fights for justice and freedom of his country nation. An author of the play beholds in his hero Shakespearean Hamlet. Proceeding out of the idea that Uzbek writer associates his hero Shakespearean image the play itself represents socially philosophical performance. It should also be noted, that Chulpan's approach as struggler for freedom and justice differs from politically adjusted ideological formations of soviet literary critics of those times. Videlicet Chulpon's peculiarity of this kind served as the base of unrecognizable relevance and modernity of the talented writer's creation.

Thanks to the independence of our Republic in the field of the literary translation shift that we see is this tendency towards direct translation. In this range poet-translator Jamol Kamol's merit is invaluable. Honored poet-translator of Uzbek Republic made a great contribution to the development of translation. His direct translations of Shakespeare works are priceless. He is one of the founders of Uzbek translation academy. Thanks to famous poet-translator practice, today Uzbek readers are able to get acquainted with Shakespeare's works directly. In order to translate Shakespeare Jamol Kamol learned English language and genius playwright's creation relentlessly. The translator has began working on this tragedy since 1970 years but those times he did not know English language. So the first translation by Jamol Kamol appeared in 1977 [6] but that was indirect one. Fourteen years later (in 1991) [3] translator remade the first version and that was direct translation of the tragedy "Hamlet".

I remember says Jamol Kamol “in 1976’s spring I gave my translation of the tragedy "Macbeth" to the Hamza theatre. In some days the great Uzbek actor Abror Hidoyatov who played many Shakespearean images not only on Uzbek but on foreign stages also, mentioned that he liked Jamol Kamol's translation and that theatre group is going to stage it. Then an actor asked to retranslate "Hamlet" for theatre. -But, what about Maksud Sheikhzade's translation? Answered Jamol Kamol surprisingly.

Because those times Maksud Sheikhzade's translation of "Hamlet" tragedy considered as the best one.

-Maksud Sheikhzade's translation of "Hamlet" tragedy is also good but not suitable for scene.

So, the request of Abror Hidoyatov became the as main reason for the appearance of the direct translation of "Hamlet" tragedy.

Let us bring some comparative analysis of tragedy translation made Uzbek and Russian translators.

When Hamlet speaks to his mother in Gertrude's room he describes the present king as follows: 


\section{HAMLET: $\quad$ A murderer and a villain;}

A slave that is not twentieth part the tithe

Of your precedent lord; a vice of kings;

A cutpurse of the empire and the rule,

That from a shelf the precious diadem stole,

And put it in his pocket!

[el. r.]

\section{QUEEN GERTRUDE: No more!}

\section{HAMLET: $\quad$ A king of shreds and patches,-}

In Russian we can see as

Гамлет:

Убийияа и холоп;

Смерд, мельче в двадиать раз одной десятой

Того, кто был вам мужем; иут на троне;

Вор, своровавший власть и государство,

Стянувший драгоценную корону

И сунувший ее в карман!

$$
\text { [el.r.] }
$$

\section{Королева:}

\section{Довольно!}

Гамлет:

Король из пёстрых тряпок...

Гамлет: ... с убийцей и скотом,

Не стоящчи одной двухсотой доли

Того, что тот. С петрушкой в королях.

С карманником на царстве. Он завидел

\section{Венеи на полке, взял исподтишка}

\section{И вынес под полою.}

Королева:

Гамлет, сжалься!

Гамлет:

Со святочной игрушкою...

[9] [el.r.]

In Uzbek it is given as follows:

Хамлет : Яна ким билан-

Қотил билан, хуайвон билан, бир муртад билан, Падаримнинг тирновига

арзимайдиган

Қирол кийимини кийган қўхирчоқ билан,

Салтанатга човут солган құароқчи билан.

Тожни токчада куррибоқ, куллтиққа урган,

Уни этак остида суинг угхирлаб

чиққан -

Ўдри билан.

Хамлет: Бир олчоқ билан!

[3, 28.]

Хамлет:

Сизга хуамёстику булган қ̧отил ва хуайвон

Мархумнинг битта хуаром тукича эмас.

Сизни қуйнига олган шоху эмас-

aйёp,

У тахт узра ўлтирган битта кисабур,

Токчада тожни курриб уузирлаган пес.

Малика: Хамлет, рахм эт!

Хамлет:

Ёрингиз бир масхуарабоз..

[2, 152].

\begin{tabular}{|c|c|c|c|c|}
\hline Original text & $\begin{array}{l}\text { M.Lozinskiy's } \\
\text { translation }\end{array}$ & $\begin{array}{l}\text { B. Pasternak's } \\
\text { translation }\end{array}$ & J. Kamol's translation & $\begin{array}{l}\text { M. Sheikhzade's } \\
\text { translation }\end{array}$ \\
\hline $\begin{array}{l}\text { A murderer and a } \\
\text { villain }\end{array}$ & Убийца и холоп + & с убийцей и скотом + & $\begin{array}{l}\text { Қотил билан, хайвон } \\
\text { билан, бир муртад } \\
\text { билан }+\end{array}$ & $\begin{array}{l}\text { Сизга хамёстиқ } \\
\text { бўлган қотил ва } \\
\text { хайвон + }\end{array}$ \\
\hline $\begin{array}{l}\text { A slave that is not } \\
\text { twentieth part the tithe } \\
\text { Of your precedent lord }\end{array}$ & $\begin{array}{l}\text { Смерд, мельче в } \\
\text { двадцать раз одной } \\
\text { десятой } \\
\text { Того, кто был вам } \\
\text { мужем + }\end{array}$ & $\begin{array}{l}\text { Не стоящим одной } \\
\text { двухсотой доли } \\
\text { Того, что тот + }\end{array}$ & $\begin{array}{l}\text { Падаримнинг } \\
\text { тирноғига } \\
\text { арзимайдиган -- }\end{array}$ & $\begin{array}{l}\text { Мархумнинг } \\
\text { битта харом } \\
\text { тукича эмас --- }\end{array}$ \\
\hline a vice of kings & шут на троне + & $\begin{array}{l}\text { С петрушкой в королях } \\
+\end{array}$ & $\begin{array}{l}\text { Қирол кийимини } \\
\text { кийган қўғирчоқ } \\
\text { билан --- }\end{array}$ & $\begin{array}{l}\text { Сизни қўйнига } \\
\text { олган шох эмас - } \\
\text { айёр --- }\end{array}$ \\
\hline
\end{tabular}




\begin{tabular}{|c|c|c|c|c|}
\hline $\begin{array}{l}\text { A cutpurse of the empire } \\
\text { and the rule }\end{array}$ & $\begin{array}{l}\text { Вор, своровавший } \\
\text { власть и } \\
\text { государство, + }\end{array}$ & $\begin{array}{l}\text { С карманником на } \\
\text { царстве }+\end{array}$ & $\begin{array}{l}\text { Салтанатга човут } \\
\text { солган қароқчи } \\
\text { билан }+\end{array}$ & $\begin{array}{l}\text { У тахт узра } \\
\text { ўлтирган битта } \\
\text { кисабур + }\end{array}$ \\
\hline $\begin{array}{l}\text { That from a shelf the } \\
\text { precious diadem stole }\end{array}$ & $\begin{array}{l}\text { Стянувший } \\
\text { драгоценную корону } \\
+\end{array}$ & $\begin{array}{l}\text { Венец на полке, взял } \\
\text { исподтишка + }\end{array}$ & $\begin{array}{l}\text { Тожни токчада } \\
\text { кўрибоқ, кўлтиққа } \\
\text { урган + }\end{array}$ & $\begin{array}{l}\text { Токчада тожни } \\
\text { кўриб ўғирлаган } \\
\text { пес+ }\end{array}$ \\
\hline $\begin{array}{l}\text { And put it in his } \\
\text { pocket! }\end{array}$ & $\begin{array}{l}\text { И сунувший ее в } \\
\text { карман! ++ }\end{array}$ & $\begin{array}{l}\text { И вынес под полою } \\
\text { - }\end{array}$ & $\begin{array}{l}\text { Уни этак остида } \\
\text { сўнг ўғирлаб чиққан } \\
-\end{array}$ & --- \\
\hline No more! & Довольно! + & Гамлет, сжалься! -- & Аясанг-чи! -- & $\begin{array}{l}\text { Хамлет, рахм эт! } \\
--\end{array}$ \\
\hline $\begin{array}{l}\text { A king of shreds and } \\
\text { patches }\end{array}$ & $\begin{array}{l}\text { Король из пёстрых } \\
\text { тряпок }++\end{array}$ & $\begin{array}{l}\text { Со святочной } \\
\text { игрушкою... -- }\end{array}$ & $\begin{array}{l}\text { Бир олчоқ билан! } \\
\text {-- }\end{array}$ & $\begin{array}{l}\text { Ёрингиз бир } \\
\text { масхарабоз... --- }\end{array}$ \\
\hline
\end{tabular}

Here it means («++»full compliance, «+» partly, «— no compliance).

1) Claudius is a murderer and usurper he is "A king of shreds and patches". In his text Shakespeare used alliteration: as A murderer, A slave, A cutpurse, a vice of kings, That from, And put; synonymic repetition: as murderer and a villain, A slave that is not twentieth part the tithe, a vice of kings; A cutpurse of the empire and the rule. In the above given table we can observe how translators could recreate the original text. The more compliances are observed in M. Lozinskiy's translation, when other translators chose free translation way. All translators managed to save the spirit of the original text. Talented translator-poet Jamol Kamol also proved that Uzbek poetic word saves the power of Shakespeare's passion.

\section{CONCLUSION}

From the depth of his poetic and translator talent he strives to unite accuracy with poetic naturalness and fluency in the target language. The image of Hamlet becomes familiar and closer to Uzbek readers. Translating Shakespeare's works translator rejected literalness and modernized the language. Jamol Kamol embodied the tragic hero. In his execution of tragedy Jamol Kamol translated elevated diction of Shakespeare into a vernacular language. Uzbek translator saved the tones expressed in Shakespeare's tragedy and managed to recreate individuality and compelling power of the hero nobleness.

\section{REFERENCES}

1. Чўлпон. Асарлар: Уч жилдлик / О.Шарафиддинов тахрири остида. Ж.І. Шељрлар. Драмалар. Таржима. - Т.: Ғафур Ғулом номидаги Адабиёт ва санъат нашриёти, 1994. - 448 б.

2. Вильям Шекспир. Хамлет, Дания Шахзодаси. Тошкент, 1948 - 148 б.

3. Вильям Шекспир. Сайланма. Уч жилдлик. Учиничи жилд. (Инглиз тилидан

4. Ғ. Саломов. Тил ва таржима.Ўзбекистон ССР “Фан” нашриёти. Тошкент -1966.

5. Иброхим Хақкул. Ижод иқлими. Тошкент.Ўзбекистон Республикаси. Фанлар академияси.”Фан” нашриёти 2009 Б.-388. б. 71 .

6. Шекспир В. Гамлет. Дания шахзодаси. Жамол Камол таржимаси ( в рукописи). Тошкент, 1977, -156 б.

7. http//Shakespeare/mit/edu/hamlet/ful/html/

8. http://thelib.ru/books/shekspir_uilyam/gamlet_princ_datskiy_permlozi nskiy-read.html

9. http://www.theatre-library.ru/files/sh/shakespeare/shakespeare_20.htm Вильям Шекспир. Гамлет, принц датский (пер.Б.Пастернак) 